\title{
Second Wave of COVID-19 Infection: An Indian Perspective
}

\author{
Dhastagir S Sheriffi
}

\begin{abstract}
The second wave of coronavirus disease-2019 (COVID-19) infection in India has taken by shock, and all the government machinery is left wanting. There was widespread reporting of a sudden surge in infections, which has led to a scarcity of health personnel as well as equipment including oxygen cylinders. Many journals including Lancet have published articles trying to focus on the inadequate measures taken by the Government of India. India is a country with a population of 1.2 billion people. However, it has alerted every sphere of human activity from individuals to the community to be aware of the virus and its impact on human lives. The present grim situation has made common man ask from where the virus originated and why it has taken so much time to find out the intermediate host for human transmission. It has also warned that reputed journals must take into serious consideration while publishing public statements that the virus is from a natural source without any concrete evidence to substantiate the statement. One of the authors of the statement has a conflict of interest. India is a resilient country that has shown in its fight to face the COVID-19. The government and other institutions need to be more prepared to face future waves of infection.

Keywords: Awareness, COVID-19, Health-seeking behaviors.

Annals of SBV (2021): 10.5005/jp-journals-10085-9104
\end{abstract}

\section{INTRODUCTION}

The editorial in Lancet regarding the handling of second wave of coronavirus disease-2019 (COVID-19) pandemic in India exposed insufficient preparation of the Government to tackle and fight the infection.

The second wave of COVID-19 infection in India has taken everybody by shock. The exponential increase in the number of infections and the unimaginable scenes of despair paint a picture of gloom and helplessness. Government machinery and private organizations do not have the facilities or manpower to fight the infection in a country with 1.3 billion people. The sudden shortage of oxygen cylinders, ventilators, and beds in COVID hospitals has shown what the virus can do. The scenes of people waiting for treatment near the hospitals and the burning of dead bodies in the open reflect human tragedy in its gruesome form. Questions have been asked how such a wave has hit India and why the government is not prepared to face the infection. ${ }^{2}$

\section{Peltzman Effect}

The scenes of mass congregation of pilgrims in millions, political rallies, and election fever have made ordinary citizens vulnerable to such infection. The mental fatigue and possible relaxed attitude in following the personal preventive measures like wearing face masks, social distancing, and hand hygiene have been suggested as few of the possible factors for such a surge in infection. They call it the Peltzman effect. ${ }^{3}$

Peltzman had suggested to install seat belts, disk brakes, and protective gear to reduce the death due to automobile accidents. This resulted in people being very relaxed in following the guidelines to stay safe. It was shown that the rate of death came down but the number of automobile accidents increased. People were religiously following the guidelines during the initial first wave of infection in 2020 due to the fear of getting infected. In the subsequent year, people started relaxing in their personal protection making them vulnerable to infection. ${ }^{4}$
Department of Biochemistry, Benghazi University, Benghazi, Libya

Corresponding Author: Dhastagir $S$ Sheriff, Department of Biochemistry, Benghazi University, Benghazi, Libya, Phone: +09003159147, e-mail: drdsheriff@gmail.com

How to cite this article: Sheriff DS. Second Wave of COVID-19 Infection: An Indian Perspective. Ann SBV 2021;10(2):29-30.

Source of support: Nil

Conflict of interest: None

\section{Vaccination}

The campaign to vaccinate and its implementation added up to such a fearless attitude thinking that people are vaccinated, and therefore, the transmission of infection is contained. The protocol to vaccinate first the healthcare workers, followed by elderly people of the age-group of 65 years and above, had left gaps in vaccinating the majority of the population who belong to the agegroup of 40 years and below. The number of vaccines available and its manufacture declined drastically. There is not enough stock to vaccinate people. Many Indian states faced shortage of vaccines. ${ }^{1}$

It put pressure on the government and manufacturing companies who were not prepared for such emerging situation. There was short supply of raw materials that have to be imported and shortage of funds to produce more vaccines. Apart from the shortage of vaccines there was shortage of life-saving equipment, oxygen supply and ventilators. There was a need for more health personnel to be employed or recruited to face the situation and handle cases. The second wave of infection in India has exposed the weakness in all these areas of numbers of healthcare personnel, oxygen supply, drugs, and other associated needs of care. ${ }^{1}$

\section{Social Media and Information}

The media and dissemination of proper information regarding the pandemic in its entirety need to be monitored and guided by experts. The spread of superstitious beliefs, certain religious

(c) The Author(s). 2021 Open Access This article is distributed under the terms of the Creative Commons Attribution 4.0 International License (https://creativecommons. org/licenses/by-nc/4.0/), which permits unrestricted use, distribution, and non-commercial reproduction in any medium, provided you give appropriate credit to the original author(s) and the source, provide a link to the Creative Commons license, and indicate if changes were made. The Creative Commons Public Domain Dedication waiver (http://creativecommons.org/publicdomain/zero/1.0/) applies to the data made available in this article, unless otherwise stated. 
activities like the dead bodies found in the river, and other beliefs need to be guided with sound and scientific knowledge. ${ }^{2}$

\section{Lack of Facilities and the Origin of Virus}

The deaths of hundreds of people due to lack of healthcare facilities, healthcare personnel, and inadequate preparedness by the government have a common man desperate to find solutions and answers to many questions surrounding the pandemic.

The paradoxical situation has led people to open up Pandora's Box to find the origin of SARS-2 virus. Even after 15 months of infection, there seems to be no answer to this vital question.

The authors of the Lancet statement note that scientists from several countries who have studied SARS-CoV-2 "overwhelmingly conclude that this coronavirus originated in wildlife," just like many other viruses that have recently emerged in humans. Conspiracy theories do nothing but create fear, rumors, and prejudice that jeopardize our global collaboration in the fight against this virus. We support the call from the DirectorGeneral of WHO to promote scientific evidence and unity over misinformation and conjecture. ${ }^{5}$

\section{Conflict of Interest and Scientific Statement}

Conflict of interest is defined as "a set of conditions in which professional judgment concerning a primary interest tends to be unduly influenced by a secondary interest." ${ }^{16}$ One of the authors of the Lancet statement, Peter Daszak is President of a company known as Eco Health Alliance, which has collaborated with Wuhan Institute of Virology to study bat coronaviruses. The author had conflict of interest while making the statement to the journal.

WHO commission who visited Wuhan that included Daszak as one of the members had no free access to places to visit or analyze. Rather, they with their limited freedom had to state that the virus escape from the laboratory was unlikely. It also had no concrete evidence to show the commission that the virus emerged naturally. ${ }^{2}$

\section{Intermediate Host and COVID-19}

The finding of intermediate host of transmission of SARS-2 virus even after 15 months of its spread remains a mystery. This was quite contrary to the SARS- 1 and MERS findings, which resulted in the identification of intermediate hosts within 4 and 8 months, respectively.

With no solid evidence to prove any theory, the claims of Daszak and others that the conspiracy theory is not relevant do not guarantee the creation of an artificial virus or engineered virus. Lancet being journal of great repute and standard had published statements made by scientists who had definite conflicts of interest. It needs to provide a statement regarding the present status of the pandemic including the need for transparency in dealing with such a global pandemic with developed countries participating in research that may prove harmful to the society, and the effect is deadly for the common global citizen.

The ethical principles of transparency, equality, common good and fairness, must guide every nation to impart proper care of the common man. The solidarity among all the nations to distribute and vaccinate the world population will play a crucial role in combating and curtailing the spread of COVID-19. Yet all of us have responsibility to make our lives livable even under such trying circumstances. What action we take must not affect posterity and generation to come.

\section{OrCID}

Dhastagir S Sheriff $\odot$ https://orcid.org/0000-0002-8549-5211

\section{References}

1. Editorial. India's COVID-19 emergency. Lancet 2021;397(10286):1683. DOI: 10.1016/S0140-6736(21)01052-7.

2. Sheriff DS. Second wave COVID 19 infection and the virus story. The Seventeenth International Public Health \& Bioethics Ambassador Conference (IPHA17), Los Angeles; 2021.

3. Peltzman S. The effects of automobile safety regulation. J Polit Econ 1975;83(4):677-725. DOI: 10.1086/260352.

4. Sheriff DS. Peltzman effect and ethical dilemma with COVID 19 vaccination in India. Paripex - Indian J Res 2021;10(5). DOI: 10.36106/ Paripex.

5. Calisher C, Carroll D, Colwell R, Corley RB, Daszak P, Droste C, et al. Statement in support of the scientists, public health professionals, and medical professionals of China combatting COVID-19. Lancet 2020;395(10226):E42-E43. DOI: 10.1016/S0140-6736(20)30418-9.

6. Thompson DF. Understanding conflict of financial conflicts of interest. N Eng J Med 1993;329(8):573-576. DOI: 10.1056/ NEJM199308193290812. 